eCommons@AKU

February 2012

\title{
Ways of teaching: Striving to enhance student's understanding in classroom setting
}

Zohra Asif Jetha

Aga Khan University, zohra.jetha@aku.edu

Shaneela Sadruddin Khowaja

Aga Khan University

Shamshad Begum

Aga Khan University, shamshad.begum@aku.edu

Follow this and additional works at: https://ecommons.aku.edu/pakistan_fhs_son

Part of the Nursing Midwifery Commons

\section{Recommended Citation}

Jetha, Z. A., Khowaja, S. S., Begum, S. (2012). Ways of teaching: Striving to enhance student's understanding in classroom setting. imanager's Journal on Nursing, 2(1), 4-7.

Available at: https://ecommons.aku.edu/pakistan_fhs_son/146 


\title{
ARTICLES
}

\section{WAYS OF TEACHING: STRIVING TO ENHANCE STUDENT'S UNDERSTANDING IN CLASSROOM SETTING}

\author{
By \\ ZOHRA ASIF JETHA * \\ SHANEELA SADRUDDIN KHOWAJA ** \\ SHAMSHAD BEGUM *** \\ * Instructor, Aga Khan University School of Nursing, Karachi, Pakistan. \\ ** Senior Instructor, School of Nursing and Community Health Sciences Departments, Aga Khan University, Karachi, Pakistan. \\ *** Senior Instructor, Aga Khan University School of Nursing, Karachi, Pakistan.
}

\begin{abstract}
Learning is enhanced when instruction is being designed in-relation to students' learning styles. Attention to learning styles and learner's diversity has shown an increase students' motivation towards learning. Effective teaching is defined as maximizing learner educational achievement, and teacher and student subject contentment. The key attributes of effective teaching are teacher's preparation, knowledge on the subject, attitude, enthusiasm, and content clarity. Moreover, applying various theories of learning such as behaviorism, cognitivism and humanism are the effective ways to enhance students' learning journey. Therefore, these effective teaching strategies should be promoted and encouraged in the real world of teaching.
\end{abstract}

Keywords: Effective Ways of Teaching, Class Room Setting, Teachers Attitude.

\section{INTRODUCTION}

Learning is enhanced when instruction is being designed in-relation to students' learning styles, as some are visual learners; some are auditory learners and the others are Kinesthetic learners (Understanding Diverse Learning Styles, 2008). Attention to learning styles and learner's diversity has shown an increase students' motivation towards learning (Budny, 2004). Review also suggests that learning is a two phase process, one is the perception and the other is the process. Therefore, various learning styles perceive and process the information differently (Understanding Diverse Learning Styles, 2008). Moreover, using multiple teaching strategies can be one of the best ways to adjust students learning styles.

Effective teaching is defined as maximizing learner educational achievement, and teacher and student subject contentment (Bastick, 1995). Rapport, classroom interaction, enthusiasm, clarity and learning are the five ways of effective teaching as identified in Nonis and Hudsons' (2004) studied. Bastick further added that effective teaching can be assessed by teachers' technical skills, professional competence and professional attitude. Moreover, earlier and recent studies have determined: knowledge of the subject/subject experties, adequate preparation/well-prepared and enthusiasm/motivated as crucial characteristics of a good teacher (Horngren, 1963; Tootoonchi et al, 2002; \& Colker, 2008).

Based on the real classroom scenario, this review is an attempt to analyze the effective ways of teaching that enhanced students' learning and understanding process.

\section{Scenario}

In order to assess the real world of learning, there was a chance to attend young class of $2^{\text {nd }}$ year diploma nurses who were entering into the profession within 1-1/2 year. In a big auditorium, a young teacher was supposed to teach 45 students, where her main goal as a teacher was to teach all her students in effective way. It was really a challenging and a difficult task that she had performed. The task was more perplexing when the teaching style was learner centered. Despite of all these challenges, she was able to perform her job smoothly with confidence. Now the question arise that how well she did it?

It was the first class after the semester break. Initially, she had reviewed the course syllabus in which course description, objectives and evaluation criteria were being discussed. Students' queries were also been entered and clarified. After that the session was being conducted by 


\section{ARTICLES}

setting the ground rules of the classroom. Moreover, all the content was delivered by using multiple teaching learning strategies such as over-head projector, lecture, practical demonstration (oral rehydration technique) discussion, and role-play. Throughout the session, students' participation was encouraging.

\section{Situation Analysis}

Analyzing the scenario with the principles of effective ways of teaching, it is found that the teacher was well-equipped and prepared for the topic (Horngren, 1963; Tootoonchi et al., 2002; \& Colker, 2008). As a result, she was able to move her class in sequential and reasonable direction as initially she had read the objectives, then defined the concepts and link-up with normal physiology, after that pathophysiology and so on. Moreover, when she had moved from one topic to other, first she revised the previous topic and then moved to the next topic. While delivering a lecture, she had used over-head projector a good visual aid for learners to read. However, the font size was small for a reader, especially for those who sat at the distance which could be hindrance making in students' learning. An alternative that she had done was to read from the over head and adjusts that barrier.

Knowledge and command on the subject is another attribute in effective teaching (Horngren, 1963; Tootoonch et al., 2002; \& Colker, 2008). Understanding learner's style and innovation skills are adding attributes. In the above situation, the teacher had discussed about the topic, revised and connects student's previous knowledge with current topic of the teaching. This process of reflection had been found an effective strategy, where students were able to learn and integrate their previous knowledge with the present one. In addition, she had also applied the art of teaching by controlling the well class and maintaining the pleasantenvironment.

Teachers' attitude, communication, and interpersonal relationship with the learners are also the key characteristics in effective teaching (Tootoonchi et al., 2002). In the given example, teacher had maintained the positive relationship with her learners by calling the students by their names, and if she had not known the name (as this was her class after semester break), she requested student to share the name before asking or giving the answers. Moreover, enthusiasm is one of the crucial characteristics of effecting teaching (Horngren, 1963; Tootoonchi et al., 2002; \& Colker, 2008; Saunder, 1998). Saunders (1998) further says that, "enthusiasm: use of non-verbal behavior to solicit student attention and interest". In relation with this attribute, the teacher in the above scenario had used several verbal and non-verbal clues like smiling, maintained good eye contact, and praised them by giving the answers. In addition, students' queries were entertained in a respectful manner. Throughout the session, she had continued encouraged and motivated the learners to participate in the class. It had hardly been observed that any learner was passive; thus, the entire class was interactive and lively. Hence, a teacher was able to maintain the environment of encouragement, support and confidence building.

Clarity is one of the five characteristics as defined by Nonis and Hudson (2004). Saunders (1998) defined the principle of clarity as "method used to explain or clarify concepts and principles" (Saunders, 1998). Clarification had also been observed an effective teaching method in the above situation as teacher had used the various examples from the real world of community settings related to diarrhea, she had also been emphasized the key concepts that are related to it such as water balance, electrolytes functions and deficiencies, and so on. Saunders (1988) also emphasized the principle of "interaction, techniques used to foster students' class participation". The class was very interactive and all the discussions were thought provoking for the learners as students were free to asked questions and clarified their thoughts. Thus, teacher had applied the learning-centered approach where students are expected to be active in their learning process by participating in discussion and or collaborative activities (Fosnot, 1989).

Reflecting on the whole scenario found that the teacher had applied the multiple educational theories in her class to enhance the student's learning journey. By sharing information with practical demonstration of oral rehydration technique with positive reinforcement, she had applied the theory of behaviorism. According to this theory, learning takes place via observe the information, practice 


\section{ARTICLES}

the information, and then receive reinforcement through praise (Billings \& Halstead, 1998). In addition, integration of previous content with current topic of the session, she attempt to enhance their cognitive and intellectual ability, thus she had applied the learning theories of cognitivism. Theory of Cognitivism discusses how information is processed to produce learning in order to make changes in learner's cognitive ability (Billings \& Halstead, 1998). Moreover, she had showed individual's and peer's respect with encouragement, and thus she had integrated the learning theory of humanism and caring. The bases of humanism theory are the concepts of caring, self/others respect and utilize maximize human potential. Reflecting on the whole situation under the umbrella of all these theories, we have found that the teacher had utilized the role of facilitator, guide, coach and mentor for the students throughout the process of her teaching.

\section{Conclusion}

The experienced of the whole scenario reflect that by using effective teaching strategies students' learning can be promoted. Moreover, the classroom climate, and the student's own learning needs along with teaching strategies all interact in producing cognitive and affective development. Therefore, these effective teaching strategies should be promoted and encouraged in the real world of teaching. The theories of learning should also be an integral part in order to make teaching more effective.

\section{References}

[1]. Bastick, T. (1995). 3AF: The Three-Ability Framework for Assessment in Tertiary Education. Paper presented at the 8th International Conference on Assessing Quality in Higher Education, Finland.

[2]. Billings, D. M., \& Halstead, J. A. (1998). Teaching in
Nursing: A Guide for Faculty. New York: W.B. Saunders Company.

[3]. Bundy, A. (ed) (2004). Australian and New Zealand Information Literacy Framework principles, standards and practice, 2nd edition. Adelaide: Australian and New Zealand Institute for Information Literacy.

[4]. Colker, L.J. (2008). Twelve Characteristics of Effective Early Childhood Teachers. Journal of the National Association for the Education of Young Children, 63(3):96106.

[5]. Fosnot, C. (1989). Enquiring Teachers, Enquiring Learners: A Constructivist Approach for Teaching. New York, NY: Teachers College Press.

[6]. Horngren, C.T. (1963). Teaching Methods and Participation as a major Law of Learning. The Accounting Review. 38(2):409-411.

[7]. Nonis, S. A. \& Hudson, G. I. (2004). Measuring Student Perception of Teaching Effectiveness. Retrieved on January 5, 2008 from, www.sbaer.uca.edu/research/1988/SMA/98s MA064.tx†

[8]. Saunders, P. (1998). Characteristics of Effective Teaching. Retrieved on February 28, 2004 from www.google.com.

[9]. Tootoonchi, A., Lyons, P. \& Hagen, A. (2002). MBA Students' Perceptions of Effective Teaching Methodologies and Instructor Characteristics. International Journal of Commerceand Management, 12(1):79-93.

[10]. Understanding Diverse Learning Styles. (2008). Retrieved on April 6, 2012, from, http://careers. sewanee.edu/assets/uploads/UnderstandingDiverseLearni ngstyles.pdf 


\section{ARTICLES}

\section{ABOUT THE AUTHORS}

Zohra Asif Jetha is currently working as an Instructor at the Aga Khan University School of Nursing and Midwifery, Karachi, Pakistan. She have 19 yrs of experience in various areas of nursing practice and education. Her major interests are Medical Surgical Nursing, Oncology Nursing, and Women and Child Nursing.

Shaneela Khowaja is currently working as a Senior Instructor at the Aga Khan University School of Nursing-Community Health Sciences Department, Karachi Pakistan. Shaneela teaches public health nursing, mental health nursing, and nursing courses to graduate and undergraduate nursing students; and Public Health, Epidemiology, Biostatistics courses to the undergraduates' medical students and qualitative research to the MSc Health Policy and Management students. In addition, School of Nursing she works at the international programmes to provide conceptual and technical support to nursing programmes in the countries (Afghanistan, Egypt \& Syria), where AKU has a base.

Shamshad Begum is currently working as a Senior Instructor at the Aga Khan University School of Nursing (AKUSON) Karachi Pakistan. She teaches Mental Health Nursing and Role Transition course in undergraduate programme of AKUSON. She has completed M.A in Education Health Promotion and International Development from Institute of Education University of London. Her areas of Interest are Nursing Education, Mental Health Nursing and Research on "Caring". 